Article

\title{
Reform of the Belgian Justice System: Changes to the Role of Jurisdiction Chief, the Empowerment of Local Managers
}

\author{
Emilie Dupont and Frédéric Schoenaers * \\ Centre of Research and Sociological Interventions, University of Liege, 4000 Liege, Belgium; \\ emilie.dupont@ulg.ac.be \\ * Correspondence: f.schoenaers@ulg.ac.be; Tel.: +32-04-366-3170
}

Received: 17 August 2017; Accepted: 20 December 2017; Published: 28 December 2017

\begin{abstract}
The last waves of reform that affected, and continue to affect, the Belgian legal system led to an injunction for increased responsibility on the part of local managers, the jurisdiction chiefs. This tendency was initiated in the 1990s, with the introduction of a managerial logic into the legal sphere, whereby local initiatives took precedence in the absence of any clear and binding direction. The 2014 reform project, through its three constituent pillars, led to the strengthening of this logic, to the point where it became an important subject. The jurisdiction chiefs were therefore confronted with a new type of responsibility in that they became responsible for the dissemination of managerial discourse within their local body, for the implementation of change, and, consequently, for the success of this change, while at the same time, being confronted by a state and by political authorities that preferred to take a back-seat role. By observing, from an exploratory perspective, the developments caused by this transformational dynamic with regard to the role and function of the jurisdiction chiefs, our contribution highlights the wide range of receptions and appropriations of the reform project, and the concepts supporting the founding trio of pillars, based on five emerging, empirically-established subjects.
\end{abstract}

Keywords: justice reform; empowerment; management; jurisdiction chief and local manager

\section{Introduction}

In recent decades, the Belgian justice system has been the theatre of many changes, some of which were discrete, carried out in courts of justice and in courtrooms, while others were more notorious, and were given more media attention. ${ }^{1}$ The last one, a reform of the legal landscape was introduced in April 2014. ${ }^{2}$

Based on the principle of scale enlargement, this reform re-charted the old map of the Judicial districts. It granted mobility to magistrates and court staff in the interests of enabling the system to become more fluid and flexible, qualities, which were lacking in the bureaucratic model according to some analysts and watchers (Guarnieri and Pederzoli 1996). This reform will be completed soon by the institution of autonomous management for the Judicial system and its local entities. The local bodies, in the person of the jurisdiction chiefs ${ }^{3}$, will therefore duly become responsible for the management of

1 This article has been realized with the support of BELSP0 programs PAI 7/22 and BRAIN/JAM.

2 Based on the laws of 1 December 2013 for the reform of the legal districts, and the modification of the judicial code with a view to strengthening the mobility of members of the Judicial Order (M.B. 10.12.2013) and 18 February 2014 relative to the introduction of autonomous management for the Judiciary (M.B. 04.03.2014).

3 This term includes the presidents of the courts of appeal and the labour courts, the presidents of the courts of first instance, commerce, labour, peace courts and judges of the police courts, as well as general public prosecutors (appeal level), public 
the relevant human and financial resources. Consequently, this wave of reform and new legislation means that the jurisdiction chiefs are center stage in terms of this change. The contours of their function are thus redefined under the influence of new management competencies and the empowerment for change that is incumbent upon them, following and reinforcing a trend that began in the 1990s (Schoenaers 2014). Indeed, the first steps in this transformation of the role of jurisdiction chief and the evolution of expectations concerning them have already been taken during previous reforms.

Consequently, over the course of time and subsequent legislation, the injunction for a higher degree of responsibility on the part of the heads of courts regarding to the improvement of organizational performance has increased significantly. It has taken on a new form today, and is marked by the withdrawal of the State from practical change management. Once the impetus was given, the framework was summarily defined, and a few grand principles were declared, with the political establishment adopting a back-seat role (Thunus and Schoenaers 2012), allowing for the burden of implementation and the success of the change to fall on the shoulders of the local managers (Rouleau 2005). The expectations of the Judicial authorities would thus be added to a high strategic dimension with regard to the local managers. The purpose of this contribution is to analyze the transformations of the role of Belgian jurisdiction chiefs following the implementation of a series of reforms (Box 1).

Box 1. Short presentation of the Belgian Judicial system.

The Belgian Judicial system belongs to the civil law tradition. Judges apply and interpret a set of codified rules. The Belgian Constitution established the Judicial power which is exercised by the law courts. These last constitute an independent power next to the legislative and executive powers.

Magistrates are divided into two main categories: "sitting judges" who are responsible for the adjudication of cases (also called "the bench") and " prosecurotrs" who essentially bring prosecutions in criminal law affairs (also called the "public ministry").

Belgium has five main Judicial areas (also called "Ressorts") each situated within the jurisdiction of a court of appeal. This means that Belgium counts 5 five courts of appeal. The geographical area covered by the courts of appeal are divided into judicial districts. Each district contains one court of first instance. Before the reform of 2013, there were 27 districts and therefore 27 courts of first instance. After the mergers which followed the reform, Belgium now has 12 Judicial districts. Moreover, the Judicial districts have 9 labour tribunals and 9 courts of commerce (prior to the reform there were 27 of each kind). Appeal proceedings against decisions of labour tribunals are managed by autonomous and specialized labour courts ( 5 in total) and appeal proceedings against decisions of courts of commerce are taken into account by a specialized section of the court of appeal.

One has also to note that the country includes independent and autonomous legal bodies composed of the magistrates of the Public Prosecutor's Office, dedicated to public prosecution in criminal law affairs. These bodies are attached to the different courts of first instance-labour tribunals, courts of appeal, labour courts and the court of cassation.

Finally, the districts are divided, in turn, into judicial cantons, of which there are 187. Every canton has a civil magistrate's court (also called "Peace Courts", each headed by a "judge of the peace") dealing with small conflicts between citizens. Following the same logic, the country also incorporates police courts dealing with offences concerning traffic law. There are, in total, 15 Police courts in the country, some of which are divided into local divisions.

At the higher level of judgement, we find the Court of Cassation that can be mobilized by one of the litigators (or the Public Prosecutor's office) after a judgement in appeal for which the form of the judgement is called into question (the substance of the decision cannot be disputed in front of the Court of Cassation).

The ordinary courts are organized in a hierarchy. The structure of courts is as follows in Table 1.

prosecutors and labour auditors for the public ministry. They are considered as the "local managers" in the Belgian Judicial system. 
Table 1. New Judicial landscape, number of organizations ${ }^{4}$ (Hondeghem and Broucker 2016).

\begin{tabular}{|c|c|c|}
\hline Level of Judgment ${ }^{5}$ & Courts & Public Prosecution \\
\hline Federal & $\begin{array}{l}\text { Court of Cassation (1) ("cour de } \\
\text { cassation") }\end{array}$ & $\begin{array}{l}\text { Prosecutor-general at the Court of } \\
\text { Cassation (1) ("parquet general } \\
\text { près la cour de cassation") Federal } \\
\text { Prosecutor (1) (parquet fédéral) }\end{array}$ \\
\hline $\begin{array}{l}\text { Second level judicial areas } \\
\text { ("ressort" level) }\end{array}$ & $\begin{array}{l}\text { Court of Appeal (5) ("cours } \\
\text { d'appel" Labour Tribunal (5) } \\
\text { ("cours du travail") Court of } \\
\text { Commerce (9) («tribunaux de } \\
\text { commerce») }\end{array}$ & $\begin{array}{l}\text { Prosecution-general (including } \\
\text { public prosecutors for labor } \\
\text { legislation) (5) ("parquet general } \\
\text { en ce compris l'auditorat general } \\
\text { du travail) }\end{array}$ \\
\hline $\begin{array}{l}\text { District ("arrondissement } \\
\text { judiciaire") }\end{array}$ & $\begin{array}{l}\text { Courts of First Instance }(13)(« \\
\text { tribunaux de première instance ») } \\
\text { Police Courts (15) («tribunaux de } \\
\text { police ») Labour Court (9) (« } \\
\text { tribunaux du travail ») }\end{array}$ & $\begin{array}{l}\text { Public Prosecutor's Office (14) } \\
\text { ("parquet du procureur du roi) } \\
\text { Public Prosecutor for Labour (9) } \\
\text { (also called "Labour Auditor") } \\
\text { ("auditorat du travail") }\end{array}$ \\
\hline Canton & $\begin{array}{l}\text { Peace Courts (187) (« justice de } \\
\text { paix») }\end{array}$ & \\
\hline
\end{tabular}

\section{The Contextual Setting}

\subsection{First Period of Managerialization: Big Demands for Small Reforms}

The reform of 2014, whose impacts are dealt with here in an exploratory way, is part of a trajectory that began in the 1990s, which has seen the Judiciary and its jurisdiction chiefs enter the era of New Public Management (Dunleavy and Hood 1994). A first phase of the "modernization" of justice has indeed taken place since that time, in response to the shortcomings which the Dutroux affair ${ }^{6}$ had helped to highlight, and also to the budgetary pressures facing the Belgian State (Vigour 2004).

It is interesting to note that most of the modernization requirements ${ }^{7}$ that were addressed with regard to the Judiciary ${ }^{8}$ were not subject to new and practical work procedures that would have been formally imposed by the summit (the political world or higher judicial hierarchy) in a typical "top-down" approach (Vigour 2017). Only a few measures were taken to reform certain aspects of

4 In parentheses, we give the "official" name of the judgment levels and jurisdiction types in French language (when different than English translation).

5 Remark: The Court of Assise (dealing with the most important crimes such as murders and based on a bench composed of professional judges and a civil jury) is organised at the provincial level. There are 11 of them. Recently the criminal has been reformed and the competences of the Court of Assise were reduced. In the future, the Court of Assise referral shold be an exception.

6 In 1996, a young girl was kidnapped in Belgium. Marc Dutroux, his wife and a third person were arrested. In August 1996, the police found two girls alive in a cage in Dutroux's house, and a few weeks later, four other girls, kidnapped in the years before, were found buried at Dutroux's house.

“This shocked the country enormously, especially when it became clear that Dutroux had been convicted previously as a sexual offender, and that the police had suspected him in this case, but failed to find the girls in an earlier search. The conviction grew that some of the girls could have been rescued if the police and the magistrates would have collaborated properly".

(Hondeghem and Broucker 2016, p. 3)

In April 1998, Dutroux escaped from a courthouse due to the carelessness of a police officer. He was captured a few hours later, but both the Minister of Justice and the Minister of Internal Affairs resigned. The 'Dutroux-case' triggered political debates regarding failures in the Belgian criminal justice system. Since that time, the Belgian Justice System has been involved in important and deep reforms.

7 Formulated by the political class but also by the media and civil society.

8 Which could be summarised around the notion of "strengthening the profile of the public service" with the objective of improving quality, efficacy, efficiency, and transparency. 
the life of the courts: the signing of the Octopus Agreement of $1998^{9}$; the sanctioning of the creation of the High Council of Justice (HCJ), now responsible for the nomination and appointment of the jurisdiction chiefs (in place of the Justice Minister); the establishment in 2000 by the HCJ of general case files for specific management skills and for the functions of jurisdiction chiefs; the introduction in 2006 of management plans for the candidate-managers of courts, integrating a series of objectives for the forthcoming years; the establishment, the same year, of fixed terms of mandates for jurisdiction chiefs, the renewal of which was subject to "evaluation", and to the approval of the HCJ; the writing of annual operation reports within the districts, marking the beginning of a logic of justification and a rendering of accounts that had been absent up to then (Hondeghem and Broucker 2016).

Thus, the centre of gravity of the managerialization of the justice system during the period 1990-2010 was essentially located at a local level, within the front-line districts. While it is true that, until recently, there was a strong political argument made for the requirements of improved jurisdiction performance (Marchandise 2013), this was never followed up by meaningful reforms. Consequently, in order to meet the new requirements, it seems that it was the local courts that introduced the most significant initiatives. The local jurisdictions, under the direction of their managers, launched programmes to reform their ways of working. At the same time, the reality of reforms (mirroring the real intensity of change) was also restricted by available local resources that could be practically invested in terms of the different processes. As these resources were limited, we can estimate that, overall, the changes within the judiciary took place in a disorganized manner, without any clear outline and without real overall structural change (Fijnaut 2001; Daems et al. 2013).

The managerial rhetoric, however, significantly penetrated all of the organizational strata and some practices did evolve, demonstrating the performance-improving character of this argument (Delvaux and Schoenaers 2009). The real change therefore seems to have taken place on the margin of the local entities depending on the initiative of local managers, who were, to a greater or lesser extent, proactive in this area (Ficet 2010). Their role, at this time, was reinforced in relation to that during the previous period when they were seen mainly as somewhat passive "administrator-coordinators" (Ackerman and Bastard 1988) in the sense of traditional administrative science theory (Warwick 1975; Wheeler and Whitcomb 1977). This process of introducing a managerial logic by local orders, also made it possible to demonstrate the fact that, if there is genuine "pressure" to reform, modernize, and improve the performance of an institution, there is not, at the same time, "sanctions" in the event of poor results (Pichault and Schoenaers 2012).

\subsection{The Reform of 2014: A Change in the Management Paradigm for Jurisdiction Chiefs}

After a succession of aborted attempts, the Justice Minister, Annemie Turtelboom, an economist by training, was tasked in 2011 with completing the reform that begun during the previous term. Two legal texts, which were devised and discussed in 2011, were voted upon in 2013 and 2014, respectively.

This first law (1 December $2013^{10}$ ) contained two essential pillars. The first pillar relates to a new judicial geography, with the creation of a new territorial division of the Justice system, which would now be based on twelve judicial districts instead of the original twenty-seven. The number of courts of appeal and labour courts remained unchanged, because there were still five courts in each category. All the aforementioned jurisdictions saw the creation of new jurisdiction chief positions which would be allocated to them subject to calls for applications (which meant that each former jurisdiction chief, whose jurisdiction had been restructured, would have to reapply without being guaranteed reappointment). In July 2014, practically all of the jurisdiction chiefs were named by the

9 The Octopus Agreement was signed by the eight democratic political parties present in Parliament after a week-end of crisis meetings. These meeting followed the escape attempt on the part of Marc Dutroux. The Octopus Agreement contained a set of decisions and principles aimed at reorganizing the police and justice departments.

10 Loi du 1er décembre 2013 portant réforme des arrondissements judiciaires et modifiant le Code judiciaire en vue de renforcer la mobilité des membres de l'Ordre judiciaire (M.B. 10.12.2013). 
Justice Minister. Each candidate then had to write and submit a management plan and have a hearing by the High Council of Justice. All of the previous justice locations (the places where the courts of justice linked to the 27 former districts were located) were initially maintained, in order to ensure the principle of proximity for citizens, and were placed under the management of a divisional "president", "prosecutor", or "labour auditor" (the former jurisdiction chiefs who were not appointed as jurisdiction chiefs in the newly created entities, ending their term of office as the head of these divisions).

The second principle pillar of the law was "mobility". One of the objectives of the scale increase was to facilitate increased mobility on the part of magistrates and the judiciary staff members. For example, magistrates could be subject to being moved between the different divisions of the new legal districts (the result of the merger of former districts). The objective behind this facilitation of mobility was to enable the jurisdiction chiefs to deal with unexpected events (long-term illness of one or several magistrates, temporary work overload in a given body, etc.), while guaranteeing greater flexibility.

\subsection{The Law of 18 February 2014}

The second law ${ }^{11}$, voted on in February 2014, revealed the intentions of the political authorities: "The objective was to bring about the decentralization and transfer of responsibility for budget management and judiciary power in order to enable the creation of a modern, accessible and rapid justice system. The judiciary would obtain greater autonomy with regard to the management of its means. The jurisdiction chiefs responsible for achieving objectives would therefore be able to make decisions on the commitment of resources and would be accountable for their actions. The representatives of the bench and the prosecutor would be involved in this decentralization of management" ${ }^{\prime \prime 2}$.

In order to achieve these ambitious objectives, the Justice Minister, (supported by parliament which would vote on the law), taking inspiration from the suggestions of her predecessor, created an entirely new judicial architecture, and envisioned an unprecedented sharing of management skills. New bodies were therefore created in the form of the Public Prosecutor's College ${ }^{13}$ and the College of the Courts and Tribunals ${ }^{14}$ (Piraux 2017). These would be responsible for the distribution of resources between the local Judicial bodies that they would establish with the approval of the Justice Minister. These local entities would therefore autonomously manage their resources, in keeping with the management plans they would agree with the new bodies (see Figure 1).

1 Loi du 18 février 2014 relative à l'introduction d'une gestion autonome pour l'organisation judiciaire (M.B. 04.03.2014).

"Presentation of motives", Document of the Bench, No. 53 3068/001.

13 The Public Prosecutor's College included six members designated by law for their function of Federal Prosecutor, as well as four elected members, three of whom are public prosecutors and a work labour auditor.

14 The College of Courts and Tribunals is composed of ten elected members, three presidents of the court of appeal, a president of the labour court, three presidents of the court of first instance, a president of the labour tribunal, a president of the court of commerce, a president of the judges of the peace, and a president of the judges of the police tribunal. 


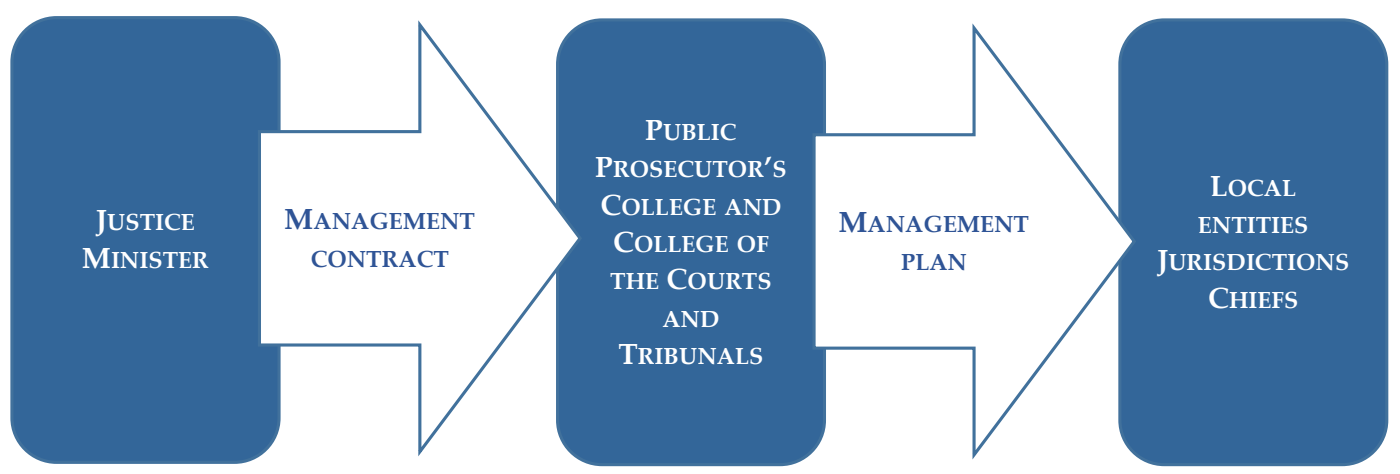

Figure 1. Contractualization mechanism—Law 18 February 2014.

In addition, each local judicial body would oversee the creation of a new organ of governance: the executive committee. This committee would be responsible for assisting the supervision, organization, and management of the jurisdiction. It would take responsibility for the drafting of the management plan, and ensure its execution. This committee would be composed of the jurisdiction chief, division chiefs, and the chief clerk of the court, or the chief secretary for the public prosecutor's office.

Each local entity would be responsible for the distribution of work between the different divisions within its territory. It would receive greater management autonomy than previously, and could therefore organize the completion of its central mission, "administering justice". This would also create the possibility of attributing a single specialization to one division which would make it the competent authority in the entire legal district. The reform also included new control mechanisms. Based on management plans established by the local bodies, the College (of Public Prosecutor or for courts and tribunals) would assess whether or not the objectives of every local jurisdiction have been achieved, and whether or not the allocated resources should be modified. Every year, both the Colleges and the local bodies would have to submit an operational report. The colleges would then send their report to the Justice Minister and Parliament annually.

It is clear that this reform, created by the laws voted in 2013 and 2014, points clearly to a managerial logic. Notions such as "contractualisation", accountability, and flexibility, to name but a few, leave little doubt as to the objectives associated with this "modernized justice system". In this context, one of the actors of the judicial organizations saw its role greatly strengthened. The jurisdiction chiefs gained more responsibilities in the context of implementing the two first pillars (effective) of the reform (operation of mergers between management entities and the mobility of magistrates). This type of responsibility was new for this category of actor (Mattijs 2006), and it seemed judicious to put into perspective the way in which they are able, in practical terms, to fulfil their role and function within this new context.

The next part of this contribution aims at analyzing the way in which the reform is put in practice by the local managers. To do this, we have conducted empirical research involving data collection centered on the local management practices.

\section{The Methodological Approach: Qualitative Empirical Research}

Our contribution is based on empirical data collected through the use of qualitative research, which began in June 2014, and which is currently continuing. This proposes to articulate a triple research methodology in order to reinforce the validity of the results, through complementary logic (Peretz 2004). 
A first set of semi-structured interviews was conducted with a group of fifteen jurisdiction chiefs ${ }^{15}$, who were selected based on various differential objective criteria (type of jurisdiction, court level, geographical location, participation in government, and decision-making bodies created, seniority, etc.). During these exchanges, topics such as the implementation and appropriation of the reform, practices, local specificities, difficulties, etc. were discussed in order to capture their discourses about their perception of the situation. Conducting our research from a longitudinal perspective, we extended this exercise at an interval of one and a half years, involving the same individuals in order to give evolutionary and procedural clarity to our first results. Our analysis was simultaneously enriched by carrying out semi-structured interviews with external actors ${ }^{16}$ gravitating around reform projects, and, by extension, some additional Jurisdiction chiefs.

These different sets of interviews were completed by the realization of four case studies based on a lengthy immersion phase. These case studies were intended to deepen the data by confronting the point of views of the jurisdiction chiefs and their staff. Conducted in a court of first instance, in a court of commerce, a public prosecutor's office and a court of appeal, the interviews enabled the authors to meet local stakeholders involved in the process of change, while at the same time, adding to our collection of data on the key actors of the organization who were caught between politics and the management style introduced by the jurisdiction chiefs.

Finally, the organization of two focus groups, at an intra- or inter-institutional level, allowed for an exchange of views and an elaboration of the visions of a dozen Jurisdiction chiefs from the Judicial system.

Applying a hypothetical-inductive logic to our research, we used the principles of Grounded Theory (Strauss et al. 2004) and gave primacy to the empirical data collected in the field by means of the several collection methods mentioned above. The toing and froing between collection and analysis recommended by this "spiral approach" (Glaser 2001; quoted by Guillemette 2006, p. 37) contributed to highlighting the various topics that were marked by their recurrence.

In the present contribution, we will return to five topics that emerged from our empirical data that demonstrate new procedures and work practices within the legal sphere in the context of the application of reform projects ${ }^{17}$.

\section{Developments in the Role and Function of the Jurisdiction Chiefs}

The objective of this part is to highlight the transformations that have occurred in terms of the role and function of the jurisdiction chiefs following the implementation of reform in the legal world. It should be remembered that these came into being, in the main, in the legislative documents of 1 December 2013 and 18 February 2014.

\subsection{Collegial Management through the Executive Committee}

Article 19 of the law of 18 February 2014 anticipated the creation of an executive committee within each judicial body. This new local management structure, placed under the presidency of the jurisdiction chief, is presented by a number of members of our sample population as a "real plus of the reform" (a Jurisdiction chief of the Office of the Public Prosecutor) ${ }^{18}$.

15 One president of the court of appeal, one president of the labour court, one Prosecutor General, five presidents of courts of first instance, one president of the court of commerce, one president of the labour tribunal, one president of the judges of the peace and the judges of the police tribunal, three Public Prosecutors and one Labour Auditor.

16 Members of the Institute of Legal Training, the High Council of Justice, the Public Service Federal Justice, the former Commission for Modernisation of the justice system etc.

17 In this contribution, the distinction between Judges and Prosecutors will not be used as a discriminating criterion for data analysis. Conversely, we will report, through our five themes, similar experiences in terms of the role of Jurisdiction chiefs.

18 In order to preserve the anonymity of our group of interlocutors, we will use the masculine form to identify the Jurisdiction chiefs we met when relating what they said. 
The creation of this committee put an end to a line of jurisdiction chiefs who were lonely in the management of their entity, and were sometimes perceived as autocratic and authoritarian, by requiring them to take on a collegial dimension to the management of the jurisdiction. This collegiality also consolidated the link between the administrative personnel and the magistrates, these two sets of individuals having previously evolved in parallel with each other, without any formal meetings inside the judicial body. The representation of the Administrative category was therefore guaranteed in the form of the court clerk or the chief secretary, who, up to the present, formed an "essential and fundamental pairing" with the Jurisdiction chief.

A large majority of jurisdiction chiefs considered the creation of such an executive committee as being among their highest priorities at the beginning of their term of office. The jurisdiction chiefs have often opted for the implementation of a temporary structure, made up of collaborators performing their function, while waiting for their definitive appointments by the General Assembly of the Body by the Justice Minister or by the King, leading to the continued employment or replacement of the members present.

Only one jurisdiction chief among our group was an exception to the rule. More than two years after the introduction of the reform, no executive committee had been set up within his body. His past experience of collegial management, and the participation of vice-presidents in bench management, left him a bit skeptical as to the interests of such a body ${ }^{19}$.

Once the choice was made to establish an executive committee, the jurisdiction chiefs found themselves legally constrained with regard to the basic composition of this organ, in that it invariably brought together the same actors as in the judicial body (cfr. supra). During the appointment of the division chiefs, this lack of freedom was also evident to the extent that the final choice of the representative was dependent upon the General Court Assembly or the King, based on the submission of two candidates by the jurisdiction chief. The jurisdiction chiefs were therefore likely to have to manage their body, surrounded by a team that they were not able to appoint as they would have preferred, and which might not have satisfied their expectations ${ }^{20}$.

The leeway available to the jurisdiction chiefs occurred therefore in the surplus composition of this governing body. They were offered the possibility of associating two members of the jurisdiction to the executive committee whose management competencies could be interesting for the legal body. In practice, the composition of the executive committees therefore varied considerably, depending on the needs of the body and the expectations of the jurisdiction chiefs. Some of them preferred a restricted circle that could be extended in accordance with the requirements stemming from future management autonomy ( $c f r$. third pillar of the reform relative to autonomous management), while others opted for an extended executive committee, completed by one, two, or even several specialists, allowing them to ensure the representation of the different sections or groups that made up their legal body.

Finally, this last element leads us to identify the ultimate choice that is available to the jurisdiction chiefs. The principle of responsibility on which the executive committee was constituted was left exclusively to the jurisdiction chiefs. Cross-investment, beyond the geographical limits of the divisions of the legal districts with regard to a subject or section was, therefore, favored by many Jurisdiction chiefs. Conversely, none of them preferred local responsibilisation situated in a geographically-defined

19 "The vice-presidents [ ... ], their main function was to judge [ . . ] but if you look at [their] job description it means being involved in the day-to-day workings [ ... ]. I made a few different attempts [ ... ], [we] created a sort of college of vice-presidents to try to distribute the tasks but this was a total failure. Because they told me [ ... ], we are prepared to do the tasks of the vice-president but we need to be relieved of the jurisdictional tasks [... ]. And that is a luxury" (a jurisdiction chief of the bench).

20 "I have the problem of divisional chiefs. These should be my right-hand men therefore persons of confidence [ ... ] I was supposed to suggest candidates for my General Assembly [ ... ] but the members did not follow my suggestion for one year. Was this so that they wanted that the chosen person would not be directly in my vision and [to] weaken the President, I don't know the reasons [ ... ]. If you are given an individual you don't want, that creates problems" (a jurisdiction chief of the bench). 
area. The division chiefs then assumed the role and missions of the Jurisdiction chiefs for a defined zone. A hybrid form, joining these two modes of responsibility, was also created within certain judicial bodies, which were characterized by their extent and consequent number of divisions. Some jurisdiction chiefs, carrying responsibility to its limits, combined this double commitment with a themed investment, allowing for them to delegate some of their own responsibilities to their divisional representatives. This might be done in order to ensure exchanges with police partners, to follow up a working procedure, or to establish the hearing.

\subsection{Management of Staff Deficits by Ingenuity and Creativity}

The reform projects recently implemented were accompanied by important restrictions in terms of personnel, both in terms of administrative members and magistrates. The Justice Minister unilaterally imposed a shortage of managers without any explanation. Legally fixed at one hundred percent, the senior magistrate staff may now not exceed ninety percent, while those of administrative personnel have a set ceiling of eighty-seven percent ${ }^{21}$. The Jurisdiction chiefs may not replace any departing staff or advertise job openings without first going through these thresholds, sometimes in a significant way. A refusal to grant advances was also noted on the part of the Justice Minister. While often announced, retirements or changes of function could no longer be the object of advance publication, making it possible to limit the turnaround time between the departure of one member of staff and the arrival of a replacement. Furthermore, the opening of a vacant position often simply led to a shifting of deficit, whether internally within the same organization, through the progression of a member of staff through the hierarchy, or externally by the transfer of collaborators to other judicial bodies. Finally, according to our interviewees, the problem of staff exhaustion impacted on a significant number of districts, and stretched a management staff that was already at breaking point.

The management of these staff deficits now fell to the jurisdiction chiefs, who found themselves very isolated and ill-equipped to deal with these deficiencies. Ingenuity and creativity were part of the qualities and skills that the local managers had to have or to acquire, in order to manage these deficits and ensure the smooth running of their judicial body. The measures taken were numerous, and were seen to be as widespread and numerous in nature as the jurisdiction chiefs of our group. We will highlight some of the more prominent practices here.

The organizational measures offered a first set of possibilities for the jurisdiction chiefs. None of them used a scheduled notification process, preferring provisional measures. One jurisdiction chief opted for a transfer of case files between the chambers within his body, in order to balance the deadline for hearings, as well as the workload between his magistrates. He did this notwithstanding the allocation of "nature" codes established by decree at the beginning of the legal year. Another jurisdiction chief from our group did not hesitate to suspend a series of weekly hearings ${ }^{22}$ in such a way as to offer some relief to his administrative personnel, but giving rise to the "technical unemployment of [his] magistrates" (A head of the bench). Conversely, certain measures were taken on a long-term basis. Several jurisdiction chiefs worked on a deeper reorganization of the first activity of their district by the rationalization of the legal argument by the defense, a regrouping of hearings, the limitation of the flow of case files coming in, or the generalization of single-judge benches in civil matters, relegating collegial hearings to the point where they were the exception. Moreover, the investments made with regard to this second series of measures often hid a complementary objective because they contributed to the search for efficiency and functional efficacy that many judicial entities intended to strive for.

21 With the exception of the Brussels-based bodies whose managerial staffing is maintained at one hundred percent.

22 A measure strongly criticised by the President of the Court of Appeal, within whose jurisdiction lies the Tribunal of First Instance, whose President favoured this option. 
The call for externally sourced staff replacements by bodies with a personnel deficit, which was difficult to manage, began to multiply. Several Jurisdiction chiefs increasingly resorted to the use of non-professional magistrates. Judges and substitute judges ${ }^{23}$ were called into chambers to meet the staff shortages, and replace career magistrates, with all the difficulties that could be expected to bring in terms of the organization and management of case files in the long term. A minority of jurisdiction chiefs at the appeal level made use, sometimes in an authoritarian way, of the possibility that is offered to them by the second pillar of the reform (facilitating the mobility of magistrates), to suggest the delegation in the higher instance of magistrates who were active in the lower court. The concept of vertical mobility also finds an echo within the jurisdictions, while horizontal mobility seems to remain meaningless, as attested to by the option quoted above, favoring the suspension of court hearings for inter-jurisdictional solidarity, which should allow, by resorting to members of staff from other judicial bodies, the maintenance of the role of established audience ${ }^{24}$.

Resorting to volunteering and voluntary work constituted a precious source of aid for the jurisdiction chiefs. Whether these actors came from the legal body or were external to it, they presented themselves as a suitable labour source when it came to facing daily difficulties or developing major projects. These were notably bailiffs and court ushers that were responsible for receiving the litigants and lawyers to ensure the correct organization of hearings, and who were paid a flat-rate, whatever the extent of their personal contribution; collaborators and judicial assistants, ready to invest their free time in the development of a computer tool for their entity, and thus compensate for the failures of the central service ICT; delegated clerks who are no more than assistants or judicial assistants assuming functions above their official rank, or the use of retired secretaries, returning to the "Palais de Justice" to carry out the encoding of personnel data and maintaining the databases of the judicial entity ${ }^{25}$.

In the eyes of a large proportion of the jurisdiction chiefs who made up our sample, great hopes were placed in the forthcoming management autonomy. The will of the Justice Minister to see all of the legal organizational dispositions replaced by negotiated budgetary envelopes could, in fact, give more latitude to the jurisdiction chiefs, and allow for them to adjust their workforce in a flexible way in accordance with the logic of equivalence. This was a logic by means of which a magistrate could be substituted by court clerks, secretaries, administrative collaborators, or assistants. Such possibilities were practically impossible for the moment, due to the fixed number of court staff set out in the legal texts.

\subsection{Integration of the Rationalisation Objectives}

The transformational dynamic, which characterizes the legal world, has opened the way, and allowed for a new logic to take hold in the Judicial institution. This logic is based on an economic and budgetary baseline, which, up to the present, has not been used and recognized in the judicial bodies by the jurisdiction chiefs who have responsibility for it, despite the fact that it appeared during the last era of managerialization. Recent years have seen the reinforcement of these preoccupations, to the point of making this a big discussion point.

The reform projects initiated were presented, at first, in terms of their objectives of quality, and effectiveness and efficiency research within the Judicial system, while promoting flexibility and the specialization of magistrates to the benefit of litigants and society as a whole, as an answer to a loss of confidence in the justice system and its workings. However, the real intentions of the Justice Minister and her reform projects soon came to light. A jurisdiction chief confided in us:

23 These functions of the substitute judge can be assumed by lawyers, doctors or law graduates (Heughebaert 2012).

24 The First President of the Court of Appeal within whose jurisdiction the Tribunal of First Instance in question is located, confided to us that horizontal mobility could have, and should have, constituted a favourable option when it came to making up a deficit in staff, and allow for the carrying out of planned hearings.

25 "I always say: the law doesn't only work with volunteers". It is volunteerism pure and simple. The law works just like the Red Cross with all these volunteers today" (an assistant to a jurisdiction chief of the bench). 
"I think we are being tricked. Things are [well] presented to us. An acidic sweet has been added to the chocolate. At the moment, we are tasting the chocolate but soon you will see a grimace $[\ldots]$. It is urgent that we wake up to this fact". (a Jurisdiction chief of the bench).

The mergers between the districts, seen as a way of harmonizing practices and ensuring the equal treatment of litigants throughout the country, were soon seen to be aimed at achieving economies of scale. The application of the principle of mobility simultaneously authorized heavy cuts with regard to the hiring of court staff (cfr. supra). The management autonomy that emerged indicated the imposition of strict measures, especially in terms of meanness with regard to the release of the kilometric quotas granted to judicial bodies to defray the travel costs of their members of staff, and even the partial suppression of a series of subscriptions to legal documentation intended for magistrates and colleagues. The economies that were imposed by the Justice Minister are therefore all-encompassing, affecting, in turn, both the human and material resources of the judicial entities.

The jurisdiction chiefs of our sample seem to have based their logic progressively on this rationalization. It seems to us that it was integrated, without being accepted or recognized as legitimate, in its current form. A local dynamism therefore follows, where the personal initiatives of jurisdiction chiefs multiply with regard to the specificities of their judicial body and their vision, which must be with regard to an efficient and rationalized justice system ${ }^{26}$.

The management of libraries that have been recently merged electronically; the closure of Justices of the Peace, located in outdated buildings that are adjudged to be energy-guzzling, or the replacement of postal mailing by digital mail for some correspondences, were all measures that were adopted locally by the jurisdiction chiefs. The latter are entirely directed at the organizational and material dimensions of the judicial bodies. Most of the jurisdiction chiefs, for the moment, refuse to subscribe to the designs of the Justice Minister and to inflict the requirements of rationalization on the human capacity of their organization. This rationalization could, however, at some point in the future, reveal itself to be a potential adjustment variable, but one requiring an initial revision of the modes of functioning and work practices, which several jurisdiction chiefs are trying to sign up to currently ${ }^{27}$.

\subsection{The Jurisdictional Aspect of the Function of Jurisdiction Chiefs}

At the beginning of their mandate, most of the jurisdiction chiefs from our sample had expressed a wish to keep only a limited jurisdictional workload, or even, in some cases, to withdraw completely in order to devote themselves full-time to their role of jurisdiction chief-manager ${ }^{28}$.

This investment was an organizational as well as a personal need. It therefore involved, depending on each case, guaranteeing the role of example-setting to staff; moving between the different newly merged divisions of the legal district to identify the local ways of working, and to meet actors in the field; to personally test a procedure ${ }^{29}$ implemented in the judicial body, in order to measure its relevance or show its usefulness for colleagues, or even to remain, quite simply, close to their first function, "being a magistrate and rendering justice" 30 .

26 "Basically, I am convinced that there is a lot of saving to be made everywhere [ ... ]. I said this to the Minister: "I am convinced that savings are possible but give us time [ . . ] , six months, one year, to give you some suggestions [ ... ] intelligent savings and without stabbing the members of staff" (a jurisdiction chief of the bench).

27 [continuation of the previous extract] " ... perhaps it is necessary to work on the number of staff members but, in any case, not for now. Give us time to stabilize [ . . ] , observe how and where we could make savings [ ... ]. This requires a review of our practices and [ ... ] success [ ... ]. Later, we could do with fewer staff but we'll have to see" (a chief of the bench).

28 "I think that the captain must not be in the engine room but rather up on deck [ ... ]. This is why I do not want [to put my energy into] structurally [in hearing roles] but there are others who still like that" (a jurisdiction chief of the Bench).

29 Among these, accelerated procedures, abrogation's etc.

30 "A reason for why we must remain in the jurisdictional function, [ . . ] it is [because] we can exercise management and more management, if you lose the knowledge of what we call judging, you will perhaps become a very good manager but not within the legal machine. Just like the great restaurant owners [ . . ], there is a golden rule and that is, that they [are] still capable of going into the kitchen if ever there is a problem. And I believe that that is the basis" (a jurisdiction chief of the bench). 
This hope was often encountered at first. Several jurisdiction chiefs, therefore, undertook, a restricted number of hearings, whether these involved so-called "presidential hearings" (a jurisdiction chief of the Office of the Public Prosecutor), where the presence of the Jurisdiction chief is legally required, or the treatment, in the manner of a "dustbin-lorry" (a jurisdiction chief of the bench), of sensitive or difficult files relating to public personalities, colleagues in the judicial chain, or thorny issues ${ }^{31}$.

To this must also be added the occasional replacement of absent or incapacitated colleagues, in such a way as not to disturb the established order, or overload colleagues in the context of the current budgetary constraints.

However, for a few jurisdiction chiefs, the agreed investment in the management of jurisdictional tasks was revealed to be more consequential. Seen at the start as temporary, they sometimes lasted several months, or have only grown in relation to organizational needs ${ }^{32}$.

The difficulty here lay in the fragile balance between operational and strategic investment. Having been overwhelmed by their judicial load, certain members of our sample contributed to a diminishment of the strategic part of their function as jurisdiction chief-manager. Among them, some seem to have accepted the situation, not without resignation, and still carry out more hearings, hiding behind the difficulties and needs of their judicial body. For others, the time of immobility seems to have passed, giving way to drastic decisions, in order to join the ranks of those who, after a period of hesitation and trial and error, induced by the changing context, finally achieved the balance, shared between their responsibilities as Jurisdiction chief and a reduced level of hearings ${ }^{33}$.

\subsection{The Many Hats Worn by the Jurisdiction Chiefs}

The newly mandated Jurisdiction chiefs were confronted with a large range of possibilities. The first of these materialized within their judicial body, while wearing the hat of Jurisdiction chief, seeking the efficient and effective functioning of his jurisdiction. This took place, in part, as a result of the daily management of the body in consultation with the executive committee; the organization and planning of the work of colleagues; the representation of the body or the exercise of disciplinary power. To these missions listed in the general profiles of the jurisdiction chiefs, can be added "shortage management" (a jurisdiction chief of the bench) or, for some, a still significant investment in hearings (cfr. supra $)^{34}$.

The jurisdiction chiefs that were operating at the appeal level also assumed responsibility for the first level of justice, judicial bodies located within the jurisdiction of their Appeals Court. The power of hierarchical surveillance ${ }^{35}$, which takes place here, has many forms, formulated in accordance with the jurisdiction chiefs and their perceptions. The recognition of a hierarchical line within the Office of the Public Prosecutor also tends to formalize the meetings between jurisdiction chiefs, and to favor

31 The subjects of terrorism and radicalism are also the object of centralisation by the jurisdiction chiefs.

32 "The fact that we are chronically understaffed means that my first reflex is to say: "I'm going to look after myself". Then I realise that I can't spend enough time in jurisdictional and that I am indeed losing quality in my job as a manager because I am losing time with this sort of thing" (a Jurisdiction chief of the Office of the Public Prosecutor).

33 "There I took a decision [ ... ] to create a magistrate of reference [ ... ] which is not me [ ... ]. I will do so, [not] because I have to, but because I choose to. In this way, I will be of more use to the Institution [ ... ]. The best way to completely miss one's managerial mission, is to continue to act operationally because, in fact, you are neither one nor the other [ ... ]. Therefore, I pass the buck [ ... ] but it's not easy [ ... ] especially when everyone is complaining about being [ ... ] overloaded. In this case I say: I don't care, you are overloaded? Ah well, that makes two of us" (a Jurisdiction chief of the Office of the Public Prosecutor).

34 "The daily work of the jurisdiction chief means that he is very busy, but what is difficult is to combine roles. He has the role of jurisdiction chief but there is also everything that comes with that role [ ... ]. Therefore, it doesn't hurt [ ... ], because he has several hats" (a jurisdiction chief of the Office of the Public Prosecutor).

35 Articles 398 and 400 of Chapter I-Conditions governing hierarchy and surveillance, of Title V-Discipline, the second part: The Judicial organization, the Judicial Code of 10 October 1967. 
collective and uniform decisions. Therefore, the exchanges between representatives of the Bench, if they are in place, are more informal, and better suited to the mode of discussion ${ }^{36}$.

The reform projects initiated led to the development of logic of partnership and networking on the part of the judicial entities. The majority of the jurisdiction chiefs of our sample therefore advocated, with a certain amount of fervor, the openness of their organization, both internally and externally, through participation in multiple working groups at the local level, or even at a national level, or the conclusion of agreement protocols with various actors in the legal world. Presented as a real added value for the judicial entities, the maintenance of this logic represents, nevertheless, a non-negligible cost, a cost in terms of time, human resources, and materials, as well as an investment in staff that is difficult to support during this period of rationalization and restriction, because it means constantly dipping into a well of meagre local resources. This is true whether this investment is agreed to by the jurisdiction chief in person, or through a process of delegation to other members of the Judicial body.

To the many different hats that are linked to the judicial body placed under their responsibility, can be added, for a certain group of jurisdiction chiefs, a commitment within the newly created spheres of governance, to the reform of the justice system. This was a voluntary choice by the ten jurisdiction chiefs of the College of the Courts and Tribunals that were elected by their peers. At the same time, less than half of the members of the College of Public Prosecutor presented at an electoral college, with the other members having been appointed to their function by law (cfr. supra).

This commitment was translated into an investment and a degree of accountability in the Colleges, in the structuring of the judicial bodies, participation in meetings, or the management of topics or work groups. It was coupled alternately with, for the General Prosecutors, the presidency of the College of Public Prosecutor ${ }^{37}$.

This participation in the Colleges represents a relatively significant psychological burden, given that it involves taking the initial steps towards the justice system of tomorrow, while determining the model of autonomous management to come for the entire legal system ${ }^{38}$.

The commitment undertaken here generated, for certain jurisdiction chiefs, a sentiment of abandonment of their own judicial body. The permanent delegation of missions and tasks had to fall to the jurisdiction chief, and the incessant recourse to assistants or divisional chiefs to ensure the daily functioning of the body weighed upon certain members of the Colleges. This raised the question of an eventual renewal of the work period for the latter, or the shedding of these supplementary tasks in such a way as to allow them to refocus on their organization and their local responsibilities, both of which were already very time-consuming ${ }^{39}$.

\section{Concluding Discussion}

After a stormy period, which was punctuated by various reform attempts based on previous resurgences, the reform of the Belgian justice system has finally become a reality. Previous projects had led to the creation of a managerial logic within the legal world. In the absence of a managerial

36 "Up to the present, I have not [ ... ] organised any consultation [ ... ]. These are seminars which I have with one or other [jurisdiction chief] but I didn't do this any more [ ... ]. The jurisdiction chief's mission is not the mission of the Jurisdiction chief of the Court of Appeal [ ... ]. I know that some people do it but I don't, and nor do I have the time to do it" (a jurisdiction chief of the bench).

37 Article 184, §2, paragraph 2 of the judicial code- “'The College of the Office of the Public Prosecutor is presided over by the President of the College of Prosecutors [appointed for the current year]".

38 "In the College, it is necessary [ ... ] to constantly take decisions, over a very short time period, on matters about which I am not sure to have all the information. I find that difficult. [ . . . ] If we talk about the future or take decisions on the budget [ ... ]. Sorry, I don't know [ ... ]. Therefore, I am unhappy. I find that now, we are taking important decisions, but we are doing so with amateurs who are doing their best. It is not amazing" (a Jurisdiction chief of the bench, member of the College of Courts and Tribunals).

39 "In the College [ . . ] ], it's a work term [ . . ], I don't know if I want to do it again [ . . ]. It is fascinating because we know everything and we are in the strategic decision-making process with regard to everything that happens. But when I see the time that [that] takes me [ . . ] ], I say to myself, can I continue like that for five years [ ... ] doing four-fifths of my work [here]?" (a Jurisdiction chief of the Office of the Public Prosecutor, and member of the College of Public Prosecutor). 
framework for legislative texts, at that time the latter materialized, thanks to local initiatives, in accordance with the variable receptions and appropriations of the jurisdiction chiefs. Nonetheless, it conferred a performative character on this vague and nebulous discourse (Vauchez and Willemez 2007).

The direction given to the 2014 reform projects seem to be much more pronounced and clear. The three pillars which underpin the project support a management vision, the buzzwords of which are, to name but a few, flexibility, autonomy, accountability, and rationalization (Fabri and Langbroek 2000). These concepts have entered the discourse of the local managers, leading to a questioning of their practices and modes of operation. Despite a strong argument from the political establishment, the processes that should lead to the implementation of this ambitious reform project remain indefinite, left to the judgement of local actors, and, by extension, the jurisdiction chiefs.

It is clear that action on the ground has been fragmented as attested to by our empirical data. Each jurisdiction chief must take on board the managerial discourse and the underpinning concepts of the three pillars of the reform. Organizations are therefore shaped by the representations that are peculiar to each jurisdiction chief, his personality, and his convictions, the recognition of the specificities of each entity, and the available local forces. It seems to us therefore that the managerial discourse spread throughout, and mobilized within the judicial sphere, has an isomorphic character, in the sense of Di Maggio and Powell (1983). All of the jurisdiction chiefs are engaged in a common quest for quality, efficacy and efficiency. In other words, the repository of public politics at work in matters of judicial governance, subscribe to a common vision of New Judicial Management, based on performance and efficiency research (Muller 2015).

Notwithstanding this homogenization around managerial logic, the changes it leads to remain deeply fragmented and locally influenced. Taking account of the different local orders could be a sign of hope for the judicial body. It may, however, reveal itself to be damaging to the Judicial institution as a whole, if it leads to the multiplication of actions, due to a lack of clear guidelines and directives issued by the political authorities or by a higher court, and resulting in accrued costs locally.

Our second observation highlights the widening gulf between the prescribed role (a new and important strategic role regarding management aspects involving the definition of a local vision and strategic reasoning about means repartition) and the real role (Chappuis and Thomas 1995) of the Jurisdiction chiefs. The realities on the ground, marked, in particular, by the lack of means and staff restrictions in a context of general austerity, negatively undermined the starting certainties and plans. The jurisdiction chiefs saw themselves, in some cases, as being relegated to the role of "shortages manager" or "crisis manager" (a jurisdiction chief of the bench). Long-term planning gave way to immediate measures, intended to facilitate the daily and operational management of the judicial body. The strategic part of the function of jurisdiction chief was reduced to its simplest expression, thus distancing these individuals from the role that the reform projects seemed to intend them for and promise them, that of jurisdiction chief-manager, at the command of his local entity, and dealing with the entire range of parameters. However, with the passing of time, certain jurisdiction chiefs seem to have taken the opposing view, deciding to "make do", mobilizing their executive committee, restricting their jurisdictional workload, or making their division representatives accountable, in order to be able to maximize their strategic investment.

Finally, the slowness with which the reform projects were applied, from the outset, reflected a judiciary that was reluctant, immobile, and struggling with a modernization process that it was unprepared for. This stagnation seemed likely to lead to a watered-down implementation, shorn of the starting aspirations, and stifling motivation and good will, as attested to by many actors on the ground, contributing nothing to the reform projects. It seems to us, however, that this immobility has today given way to a form of dynamism that is contingent upon the style of management chosen by each Jurisdiction chief, and taking account of the local characteristics of each judicial body.

Author Contributions: Frederic Schoenaers conceived the research project and methods as an answer to a call for proposals from the BRAIN program of Belspo. Emilie Dupont performed the interviews and case studies and analyzed the data. The interviews of the Dutch speaking magistrate have been mainly realized by Emilie Dupont 
and Frederic Scheoaners. The paper has been written by both the authors (Section 2 mainly by Fredric Scheoaners and other sections mainly by Emilie Dupont.

Conflicts of Interest: The authors declare no conflict of interest.

\section{References}

Ackerman, Werner, and Benoît Bastard. 1988. Efficacité et gestion dans l'institution judiciaire. Revue Interdisciplinaire d'Etudes Juridiques 20: 19-48.

Chappuis, Raymond, and Raymond Thomas. 1995. Rôle et Statut. Paris: PUF.

Daems, Tom, Eric Maes, and Luc Robert. 2013. Crime, criminal justice and criminology in Belgium. European Journal of Criminology 10: 237-54. [CrossRef]

Delvaux, David, and Frédéric Schoenaers. 2009. La mesure de la charge de travail des magistrats: Analyse d'un dispositif de modernisation de la Justice. Performance Publique Larcier 2: 87-102.

Di Maggio, Paul J., and Walter W. Powell. 1983. The iron-cage revisited: Institutional isomorphism and collective rationality in organizational field. American Sociological Review 48: 147-60. [CrossRef]

Dunleavy, Patrick, and Christopher Hood. 1994. From old public administration to new public management. Public Money and Management 14: 9-16. [CrossRef]

Fabri, Marco, and Philip M. Langbroek. 2000. The Challenge of Change for Judicial Systems. Amsterdam: IOS Press.

Ficet, Joël. 2010. Entre efficience et indépendance. Le projet de 'reconfiguration du paysage judiciaire'. Journal du Droit des Jeunes 295: 36-41.

Fijnaut, Cyrille. 2001. Crisis and reform in Belgium: The Dutroux affair and the criminal justice system. In Managing Crises, Threats, Dilemmas, Opportunities. Edited by Rosenthal Uriel, Arjen Boin and Louise Kloos Comfort. Springfield: Charles C. Thomas, pp. 235-50.

Glaser, Barney G. 2001. The Grounded Theory Perspective: Conceptualization Contrasted with Description. Mill Valley: Sociology Press.

Guarnieri, Carlos, and Patrizia Pederzoli. 1996. La Puissance de Juger. Paris: Michalon.

Guillemette, François. 2006. L'approche de la Grounded Theory; pour innover. Recherches Qualitatives 26: 32-50.

Heughebaert, P. 2012. Avocat et Juge Suppléant, ou l'art de Retourner sa Toge. Available online: http:/ / www.justice-en-ligne.be/article504.html (accessed on 25 June 2017).

Hondeghem, Annie, and Bruno Broucker. 2016. From octopus to the reorganization of the judicial landscape in Belgium. In Modernization of the Criminal Justice Chain and the Judicial System. New Insights on Trust. Edited by Hondeghem Annie, Xavier Rousseaux and Frédéric Schoenaers. Berlin/Heidelberg: Springer, pp. 3-18.

Marchandise, Thierry. 2013. Concilier le management avec les valeurs du judiciaire. In Quel Management Pour Quelle Justice. Bruxelles: Larcier, pp. 81-88.

Mattijs, Jan. 2006. Implications managériales de l'indépendance de la Justice. Pyramides 11: 65-102.

Muller, Pierre. 2015. Les Politiques Publiques. Paris: PUF.

Peretz, Henri. 2004. Les Méthodes en Sociologie. L'observation. Paris: La Découverte.

Pichault, François, and Frédéric Schoenaers. 2012. Le middle management sous pression. La difficile intégration du référentiel managérial du NPM dans les organisations au service de l'intérêt general. Revue Internationale de Psychosociologie et de Gestion des Comportements Organisationnels 18: 121-50. [CrossRef]

Piraux, Alexandre. 2017. La justice sous contrat de gestion avec le pouvoir exécutif. Pyramides CERAP 27: 21-36.

Rouleau, Linda. 2005. Micro-practices of strategic sensemaking and sensegiving: How middle managers interpret and sell change every day. Journal of Management Studies 42: 1413-41. [CrossRef]

Schoenaers, Frédéric. 2014. Lorsque le management entre au tribunal: Évolution ou revolution. Revue de Droit de l'ULB 41: 171-209.

Strauss, Anselm L., Marc-Henry Soulet, Juliet M. Corbin, Stéphanie Emery, and Marc-Henry Soulet. 2004. Les Fondements de la Recherche Qualitative. Techniques et Procédures de Développement de la Théorie Enracinée. Fribourg: Academic Press.

Thunus, Sophie, and Frederic Schoenaers. 2012. When policy makers consult professional groups in public policy formation: Transversal consultation in the Belgian Mental Health Sector. Policy and Society 31: 145-58. [CrossRef]

Vauchez, Antoine, and Laurent Willemez. 2007. La Justice Face à ses Réformateurs (1980-2006). Paris: PUF. 
Vigour, Cécile. 2004. Réformer la justice en Europe: Analyse comparative des cas de la Belgique, de la France et de l'Italie. Droit et Société 56: 291-325.

Vigour, Cécile. 2017. La justice, entre institution, professions et organisation. Redéfinition des équilibres en Europe. In Justice 2020—Les Enjeux du Futur. Anvers: Maklu, pp. 49-76.

Warwick, Donald P. 1975. A Theory of Public Bureaucracy. Boston: Harvard University Press.

Wheeler, Russell R., and Howard R. Whitcomb. 1977. Judicial Administration: Texts and Readings. Englewood Cliffs: Prentice-Hall. 